\title{
Illitic substitution in micas of very low-grade metamorphic clastic rocks
}

\author{
ISABEL ABAD ${ }^{1 *}$, FERNANDO NIETO ${ }^{2}$, GABRIEL GUTIÉRREZ-ALONSO ${ }^{3}$, MARGARITA DO CAMPO $^{4}$, \\ AURORA LÓPEZ-MUNGUIRA ${ }^{5}$ and NICOLÁS VELILLA ${ }^{2}$
}

\author{
${ }^{1}$ Departamento de Geología, Universidad de Jaén, 23071 Jaén, Spain \\ *Corresponding author, e-mail: miabad@ujaen.es \\ ${ }^{2}$ Departamento de Mineralogía y Petrología and IACT, Universidad de Granada, CSIC, 18002 Granada, Spain \\ ${ }^{3}$ Departamento de Geología, Universidad de Salamanca, 37008 Salamanca, Spain \\ ${ }^{4}$ Instituto de Geocronología y Geología isotópica, Ciudad Universitaria (1428) Buenos Aires, Argentina \\ ${ }^{5}$ Área de Cristalografía y Mineralogía, Universidad de Extremadura, 06071 Badajoz, Spain
}

\begin{abstract}
The chemical compositions of micas from six well-characterised sequences have been jointly evaluated in order to analyse the behaviour of illitic substitution $\left(\mathrm{SiAl}_{-1} \square \mathrm{K}_{-1}\right)$ in relation to diagenetic/metamorphic grade. Data from 265 crystals, corresponding to 48 samples, were obtained through EDX analyses in SEM and TEM and the influence of analytical artefacts, such as contamination and alkali loss, was critically evaluated. From diagenesis to low epizone, the compositions of the micas are highly heterogeneous at the sample level, do not show systematic differences between grades, and include a significant illitic component, ranging from $\Sigma$ interlayer cations $=0.6$ to 1.0 a.f.u. At high epizone (Kübler Index $<0.2 \Delta^{\circ} 2 \theta$ ), a very significant textural change is accompanied by homogenisation of the chemical composition and a reduction of the illitic component to very low values. Our data suggest continuity in the composition between illite and muscovite and do not allow us to confirm the existence of a miscibility gap in low-T environment natural samples. Some of the mica analyses reaching Si contents of around 3.5 a.f.u. correspond to interlayercation population contents in the range of 0.6-0.7 a.f.u., indicating illitic substitution. Therefore, thermobarometry of lowtemperature phengites based only on the Si-content, without taking into account the illitic component, would result in pressure overestimates.

Resumen: Se evalúan de manera conjunta los datos químicos de micas correspondientes a seis secuencias bien caracterizadas previamente, con el objeto de analizar el comportamiento de la sustitución ilítica $\left(\mathrm{SiAl}_{-1} \square \mathrm{K}_{-1}\right.$ ), en relación al grado diagenético/ metamórfico. Se han empleado los datos químicos obtenidos mediante SEM (EDX) y TEM (AEM) de 265 cristales pertenecientes a 48 muestras. Se ha considerado críticamente la influencia de artefactos analíticos tales como la contaminación y la volatilización de alcalinos. Desde la diagénesis hasta la epizona débil, las muestras se caracterizan por mostrar micas composicionalmente muy heterogéneas, sin diferencias sistemáticas entre grados y con un componente ilítico significativo, con valores de interlaminares de 0.6 a 1.0 a.f.u. En la epizona intensa (Índice de Kübler $<0.2 \Delta^{\circ} 2 \theta$ ) un cambio textural importante acompaña a la homogeneización de la composición química de las micas con la consiguiente reducción del componente ilítico a valores muy bajos. Nuestros datos sugieren continuidad en la composición entre ilitas y moscovitas y no permiten confirmar la existencia de un hueco de miscibilidad en ambientes naturales de baja temperatura. Algunos análisis de las micas alcanzan valores de Si de 3.5 a.f.u. junto a una población de interlaminares en el rango de 0.6 a 0.7 a.f.u. que indican claramente la sustitución ilítica. Por tanto, la termobarometría de micas fengíticas de baja temperatura basada sólo en el contenido en Si sin tener en cuenta el componente ilítico, podría producir una sobrevaloración de la presión.
\end{abstract}

Key-words: illitic component, SEM/EDX, TEM/AEM, mica, low-grade metamorphism, diagenesis.

\section{Introduction}

In recent decades, despite the emergence of a considerable wealth of mineralogical information on dioctahedral micas, relatively little is known about the common mineralogical and chemical changes involved in the conversion of illitic mica to muscovite within the most abundant very low-grade metamorphic clastic rocks (see Guidotti \& Sassi, 1998 and Árkai, 2002 for a review).
The mineral illite was first described in argillaceous sediments by Grim et al. (1937), but it was not until a few decades later that Hower et al. (1963) and Bailey (1966) realized that illites in shales were not a single mineral, but a mixture of detrital and diagenetic components.

More recently, the process of illite crystallisation has been recognized as a major and widespread post-sedimentary progressive reaction series in detrital sediments: smectite $\rightarrow$ I-S, random $\rightarrow$ I-S, ordered $\rightarrow$ illite, $1 \mathrm{Md} \rightarrow$ muscovite, 
2M $\mathrm{M}_{1}$ (Srodon, 1999; Zhao et al., 1999, among others). Furthermore, according to Hunziker et al. (1986) and Livi et al. (1997), illite is replaced by muscovite through a continuous restructuring process within greenschist and higher-grade metasedimentary rocks.

Since illite samples are often a physical mixture of nonexpanding $10 \AA$ material and predominantly illitic, ordered illite/smectite mixed-layers, their actual composition is difficult to determine precisely by traditional analytical methods. Due to this difficulty, authors have proposed different theoretical compositions for illite, including, among others: (1) Weaver (1956) and Hower \& Mowatt (1966) extrapolated $0.75 \mathrm{~K}$ a.f.u. for end-member illite, using XRD and bulk chemical data; (2) Nadeau \& Bain (1986) gave a range of 0.5-0.9 a.f.u. layer charge; (3) the same range was reported by Ransom \& Helgeson (1993) using AEM as well as XRD and other analytical data; and (4) Srodon et al. (1992) concluded that illite has 0.89 fixed interlayer cations per $\mathrm{O}_{10}(\mathrm{OH})_{2}$.

Nowadays, according to the Mica Subcommittee (IMA commission on New Minerals and Mineral Names), the term illite should be used to designate interlayer-cation-deficient micas $(<0.85$ a.f.u.), as a name of a series consisting of a coupled substitution of $\left(\mathrm{SiAl}_{-1}\right)$ in the tetrahedral site and of (vacancy $\mathrm{K}_{-1}$ ) in the interlayer site (Rieder et al., 1998). According to Rosenberg (2002) the end-member of the illite series has a composition of $0.88 \pm 0.01$ interlayer cations per half cell. This compositional vector in micas has traditionally been linked to low-temperature environments (Merriman \& Peacor, 1999 and Agard et al., 2001), where it is common to find $\mathrm{K}$-mica crystals with small but significant deficits in interlayer charge (Árkai et al., 2003). Nevertheless, the role of illitic substitution in the chemical evolution of micas during prograde diagenesis and very low-grade metamorphism is still poorly understood, mostly due to the difficulty in obtaining uncontaminated in situ analyses of very small defective crystals.

Several attempts have been made to understand the formation and stability of end-member illite with respect to muscovite over the low-temperature range between 100 and $250{ }^{\circ} \mathrm{C}$ through solid equilibration experiments (Yates \& Rosenberg, 1997 and 1998). In this experimental replacement of muscovite by illite, intermediate compositions were not obtained between the end-member illite and theoretical muscovite composition, suggesting the existence of a gap between them. In contrast, and according to the hypothesis of Gharrabi et al. (1998) based on XRD studies, Rosenberg (2002) has stated that the end-member illite is not a disordered K-deficient muscovite solution but a stable, ordered structure consisting of muscovite and pyrophyllite domains and, thus, is a distinct mineral. However, this statement has not yet been supported by direct evidence, that is, by detailed TEM studies of end-member illite grains. Whether illite has its own equilibrium field at lower temperatures than muscovites, or whether its presence is only a consequence of the low activation energy of these systems in natural geological environments is a question that still has remained unsolved (Abad et al., 2003a).

In this paper, we provide high-quality in situ analyses of coexistent illites and muscovites from clastic materials of various diagenetic and very low-grade metamorphic sequences ( 265 analyses) generated in different geodynamic settings. Our aim is to evaluate the quality and significance of the data in order to examine the relationships between the chemical compositions of the micas and the metamorphic grade of the rock containing the micas, characterised by the Kübler Index (KI). Special emphasis is placed on the role of the illitic substitution mechanism towards more muscovitic compositions as metamorphic grade increases. The analyses have been obtained using electron microscopy techniques (both scanning and transmission), allowing us to document the changes in the population of dioctahedral mica in response to prograde metamorphic conditions by means of backscattered electron images, chemical analyses, and lattice-fringe images. Since any possible contaminations can be checked by means of TEM studies and because cation loss throughout the measurement procedure is minimal in SEM, the two sources of data are complementary and provide high-quality analytical data. The results presented here will thus provide a better understanding of the chemical evolution of K-mica during incipient metamorphism.

\section{Analytical methods}

Quantitative analyses were obtained by EDX on carboncoated polished samples examined by scanning electron microscopy (SEM) using backscattered electron images and by analytical electron microscopy (AEM) in transmission electron microscopy (TEM) from ion-milled grids and holey $\mathrm{C}$-coated $\mathrm{Cu}$ grids. To check the accuracy of these analytical techniques, one of the samples with a large enough grain size was also analysed by Electron Microprobe.

A Zeiss DSM 950 SEM equipped with an X-ray Link Analytical QX-20 energy-dispersive system (EDX) was used, with an accelerating voltage of $20 \mathrm{kV}$, a beam current of 1-2 $\mathrm{nA}$ and a counting time of $100 \mathrm{~s}$. Both natural and synthetic standards were employed: albite $(\mathrm{Na})$, periclase $(\mathrm{Mg})$, wollastonite $\left(\mathrm{Si}\right.$ and $\mathrm{Ca}$ ), orthoclase $(\mathrm{K})$ and synthetic $\mathrm{Al}_{2} \mathrm{O}_{3}$ $(\mathrm{Al}), \mathrm{Fe}_{2} \mathrm{O}_{3}(\mathrm{Fe})$, and $\mathrm{MnTiO}_{3}(\mathrm{Ti}$ and $\mathrm{Mn})$.

The TEM was a Philips CM20 (STEM) equipped with an EDAX solid-state EDX detector, operating at $200 \mathrm{kV}$, with a spatial resolution of $2.7 \AA$ between points. Quantitative analyses (AEM) were obtained from thin edges, using a (1000 x 200) $\AA$ scanning area. Counting times of $15 \mathrm{~s}$ and $100 \mathrm{~s}$ minimised alkali-loss problems as short counting times improve reproducibility for K, Na (Nieto et al., 1996). Albite, biotite, spessartine, muscovite, olivine and titanite standards were used to obtain K-factors for the transformation of intensity ratios to concentration following Cliff \& Lorimer (1975). Both electron microscopes are located at the C.I.C. (Universidad de Granada).

Microprobe analyses of micas were performed using wavelength-dispersive spectroscopy (WDX) on a Cameca SX50 electron microprobe at the C.I.C. The instrument was set at an accelerating voltage of $20 \mathrm{kV}$, with a beam current of $30 \mathrm{nA}$ and a beam diameter of $<5 \mu \mathrm{m}$. Data were reduced using the procedure of Pouchou \& Pichoir (1985) and the standards were albite, orthoclase, periclase, wollastonite and synthetic oxides $\left(\mathrm{Al}_{2} \mathrm{O}_{3}, \mathrm{Fe}_{2} \mathrm{O}_{3}\right.$ and $\left.\mathrm{MnTiO}_{3}\right)$. 
Fig. 1. Chemical diagrams illustrating the influence of possible artefacts in the K-dioctahedral mica composition: alkaline cation loss and contamination by chlorite, albite and quartz. Black points indicate the theoretical muscovite position.
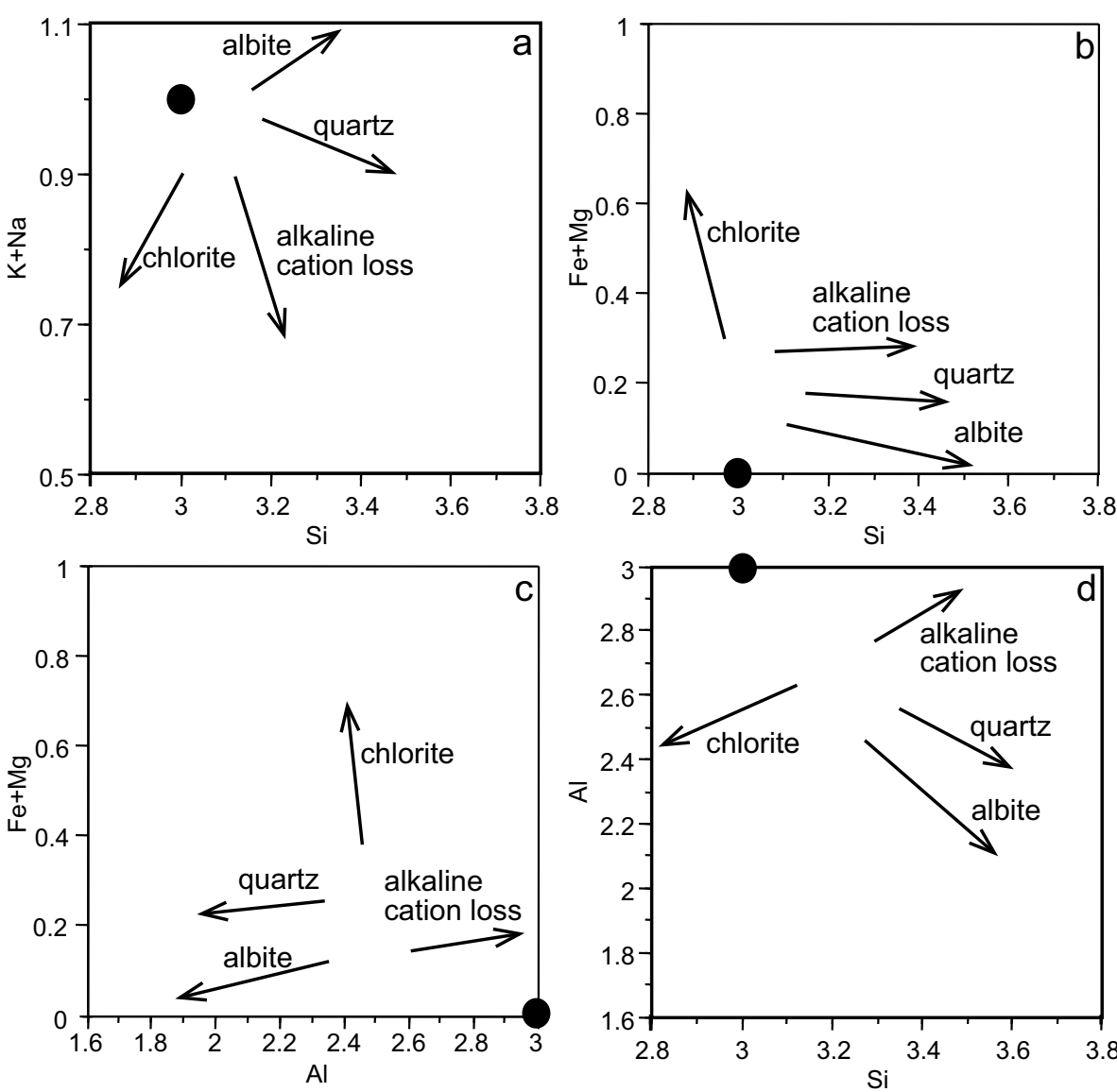

Since the very small grain sizes characteristic of lowgrade phyllosilicates preclude the conventional use of optical images to select points for analyses in situ, backscattered electron images were used as their contrast is very sensitive to small differences in chemical composition. Modern scanning electron microscopes allow very quick acquisition of these types of images and the subsequent selection of the best points to be analysed. The same mode of sample preparation - carbon coated polished thin sections - and data acquisition as for the electron microprobe is possible, the only difference being the use of EDX $v s$. WDX. One sample with a large enough grain size to be analysed with the electron microprobe was used to check possible differences between the two techniques. The results obtained were conclusive, showing very small differences between the two techniques, well below their precision level, for all the major elements involved in the chemical composition of the micas (see Table 2 in Abad et al., 2003a).

The structural formulae of micas were calculated on the basis of 22 negative charges $\mathrm{O}_{10}(\mathrm{OH})_{2}$. Unfortunately, these analytical techniques cannot distinguish between $\mathrm{Fe}^{3+}$ and $\mathrm{Fe}^{2+}$. Guidotti et al. (1994) showed that even in low-redox parageneses, approximately $50 \%$ of the total Fe in muscovite is $\mathrm{Fe}^{3+}$ and values close to $85 \%$ can be reached in oxidizing environments. Therefore, as a compromise, in the formula calculations it has been assumed that $75 \%$ of the $\mathrm{Fe}$ in micas is $\mathrm{Fe}^{3+}$.

\section{Evaluation of possible artefacts affecting the quality of chemical data}

Due to the very fine-grained nature of these samples, some data obtained using SEM had to be rejected due to contamination by the surrounding quartz, albite and/or chlorite grains. However, possible artefacts like these contaminations can be checked in TEM studies where the alkali cation loss is the most problematic question arising during the performance of the analyses, which is, in contrast, minimal when using SEM. The effects of these possible artefacts are shown in Fig. 1.

The contamination of white mica by chlorite produces an increase in the trioctahedral components ( $\mathrm{Fe}$ and $\mathrm{Mg}$ ) correlated with a drop in the Si content and a decrease in the interlayer cations. The results obtained depict precisely the opposite tendency, as can be observed in Fig. 3 and 4. Additionally, although the octahedral cation sum in micas is very sensitive to chlorite contamination, sums abnormally higher than 2 a.f.u. are absent in the analyses (Table 1, which is deposited and available directly from the authors or the EJM editorial office in Paris). We can therefore conclude, in the light of the obtained analytical results, that contamination by chlorite has been successfully avoided and cannot be responsible for the chemical tendencies described in this work.

The interference caused by quartz contamination results in a drop in the interlayer cation content and the dioctahedral 

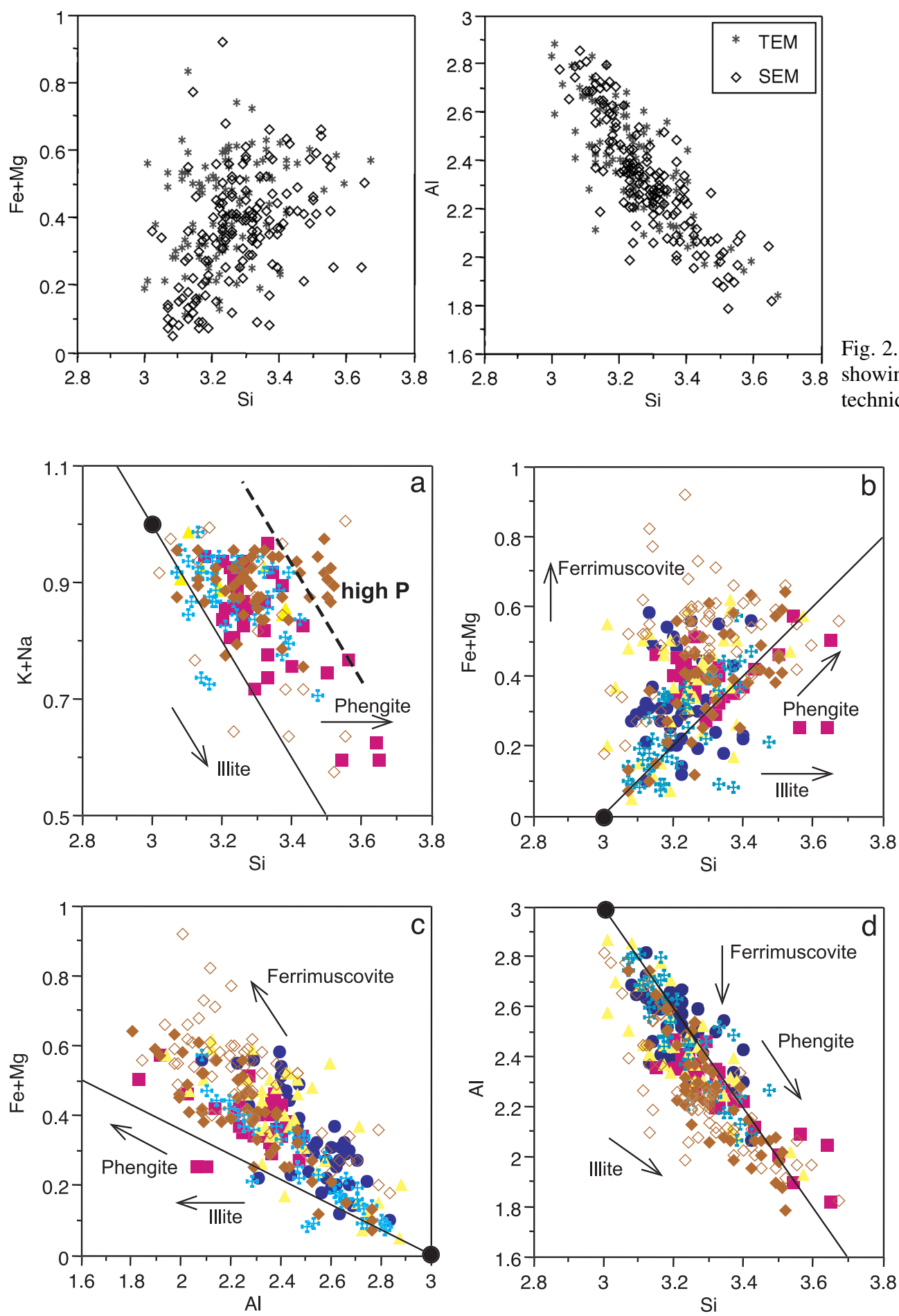

\begin{tabular}{|lll|}
\hline Ossa Morena shales & Sierra Espuña & Talas \\
Narcea slates & $\$$ South Portuguese Zone & $\diamond$ Puncoviscana \\
\hline
\end{tabular}

Fig. 2. Plots of Si vs. Fe+Mg and $\mathrm{Si} v s . \mathrm{Al}$ showing the data in function of the two techniques used: SEM and TEM.
Fig. 3. Diagrams of the chemical composition of micas corresponding to all the studied sequences. Black points and solid lines respectively indicate the theoretical muscovite position and corresponding exchange vectors. SEM and TEM data except for the $\mathrm{Si}-\mathrm{Na}+\mathrm{K}$ plot where only SEM data have been used. and trioctahedral components. In addition, this drop is coupled with an increase in the Si content, the same effect as can be caused by a presence of albite. The latter, however, causes an increase of the interlayer cation content due to the $\mathrm{Na}$ in the albite (Fig. 1a). The most evident effect related to the cation loss is a decrease in the interlayer content together with an increase principally in the $\mathrm{Si}$ and $\mathrm{Al}$ contents in order to compensate for the deficit in the interlayer charge (Fig. 1).

The effects of cation loss, contamination by quartz, or their combined influence on the analytical results can be de- 

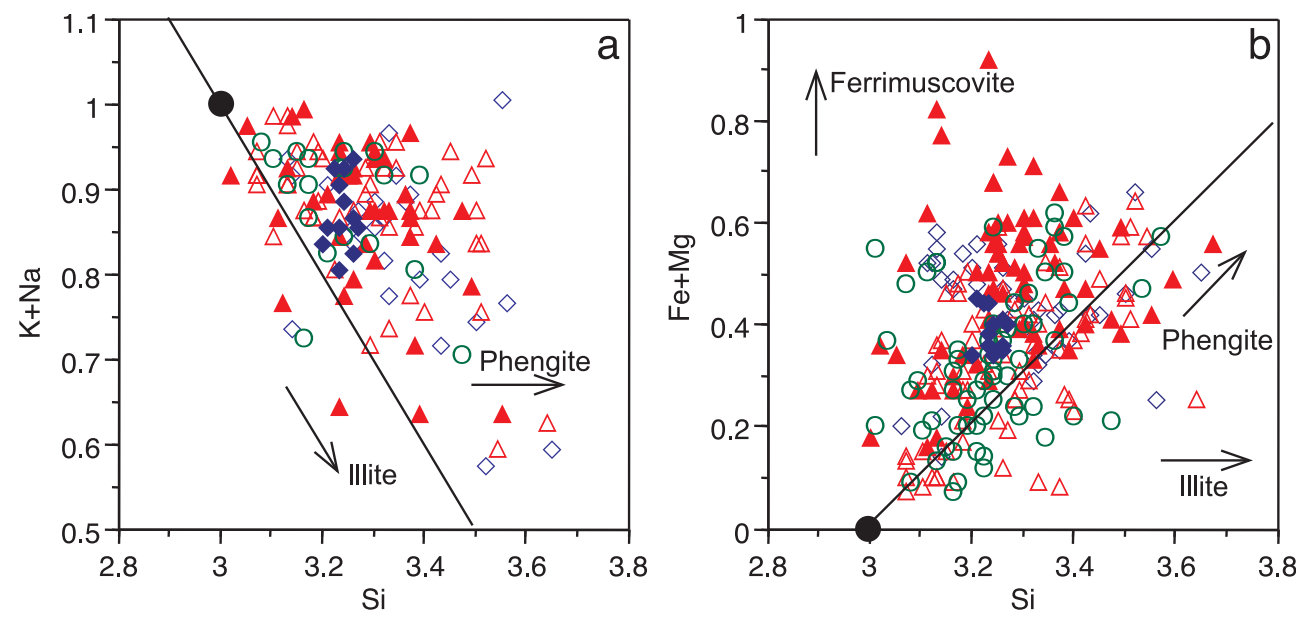

Fig. 4. Diagrams of the chemical composition of micas corresponding to all the studied sequences and in function of the Kübler Index (KI). Black points and solid lines respectively indicate the theoretical muscovite position and corresponding exchange vectors. SEM and TEM data except for the $\mathrm{Si}-\mathrm{Na}+\mathrm{K}$ plot where only SEM data have been used.
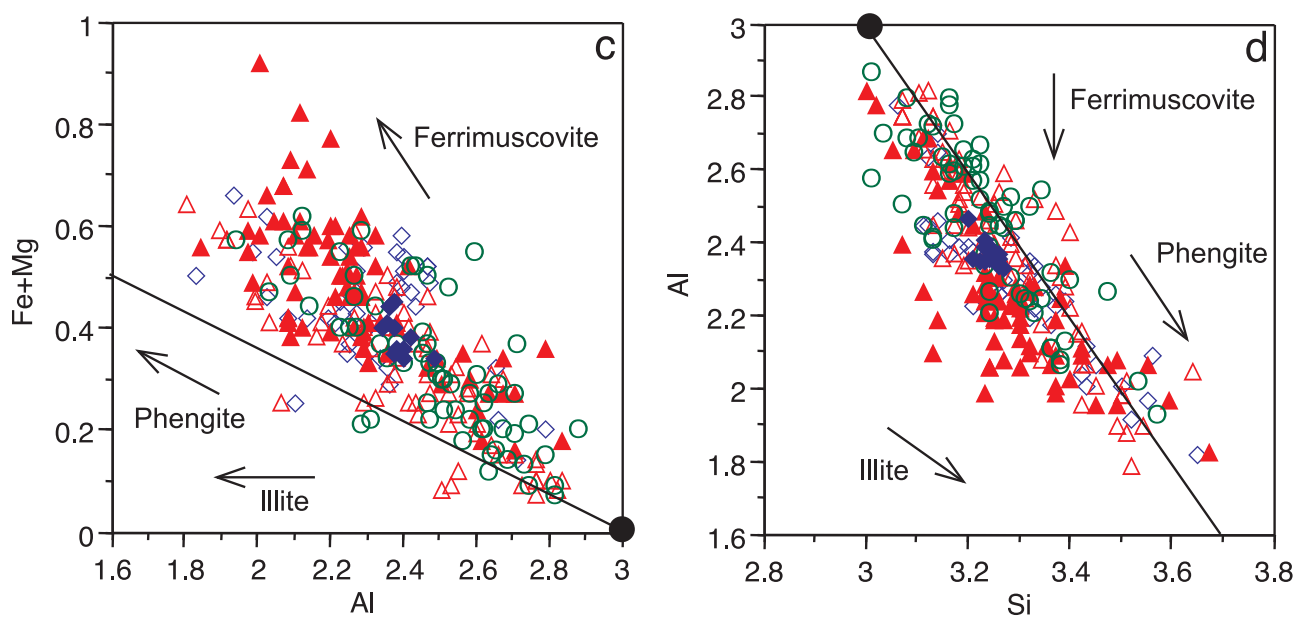

$\diamond$ epizone $\mathrm{KI}<0.2 \Delta$ high anchizone $\mathrm{O}$ diagenesis
$\diamond$ epizone $\mathrm{K} \mid>0.2 \Delta$ low anchizone

termined by comparing the TEM and SEM data. In TEM studies contamination is drastically lowered because the area selected for analysis is routinely checked for purity through electron diffraction in powder samples and through lattice images and electron diffraction in ion-milled samples. Therefore, the presence of a contaminant phase in significant amounts would be evidenced by an extra lattice in electron-diffraction diagrams and anomalous spacing in lattice-fringe images. As a drawback, cation loss may have dramatic effects in TEM analyses. In contrast, SEM analyses are hardly influenced by cation loss, but may be more affected by quartz contamination. Since a small loss of alkali cations is also possible under SEM, the possibility of a composite effect of alkali cation loss + quartz and/or chlorite contaminations should also be taken into account. As the effect of these artefacts or their combination on the two employed techniques is substantially different, if they were responsible for the chemical tendencies commented on below, a significant difference would be evident when comparing $\mathrm{TEM}$ and SEM data in $\mathrm{Al}-\mathrm{Fe}+\mathrm{Mg}$ or $\mathrm{Si}-\mathrm{Al}$ plots.

\section{Samples}

Data shown here correspond to micas from clastic materials of various intensively studied very low-grade metamorphic sequences from extremely different geodynamic settings. The Kübler Index values of these sequences were determined on the air-dried $<2 \mu \mathrm{m}$ fraction obtained according to IGCP 294 IC Working Group recommendations (Kisch, 1991), using the international standards of Warr \& Rice (1994). A detailed explanation on sample preparation, experimental conditions and complete KI data can be found in the studies referred to below.

Narcea Slates. These samples, covering the anchizonal and epizonal ranges, are located along the very low- to lowgrade metamorphic transition in the Variscan belt of NW Spain (Gutiérrez-Alonso \& Nieto, 1996). Electron microscopy studies (SEM and HRTEM) have shown that the effect of tectonic deformation was fundamental both in the development of a metamorphic texture and in the approach to chemical equilibrium in this sequence (Abad et al., 2003a). 


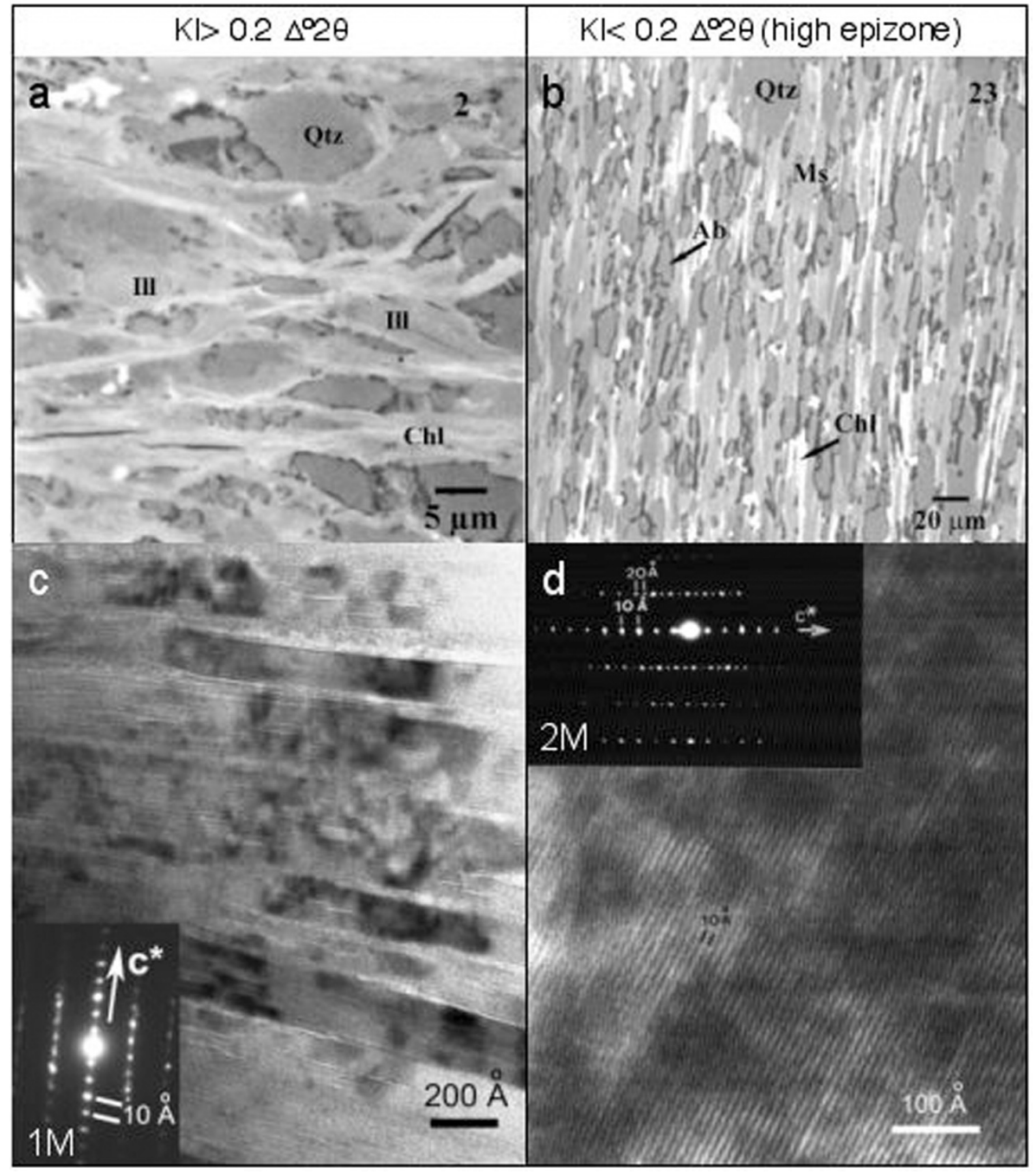

Fig. 5. Typical representative textures of mica-rich parts at backscattered electron scale (up) and lattice fringe scale (down): a) Sample 2 from Narcea Antiform, anchizone; b) Sample 23 from Narcea Antiform, epizone; c) Sample C-90-7 from Ossa-Morena Zone, deep diagenesis; d) Sample PU36 from Puncoviscana Formation, epizone. Insets (Fig. 5c and d) present electron diffraction patterns showing the corresponding mica polytype.
South Portuguese Zone sequence. This sequence corresponds to the very low- to low-grade metamorphism transition in the Variscan belt of SW Iberia and covers all ranges from diagenesis to epizone. XRD and AEM reveal a trend for the micas towards more muscovitic compositions related to the increasing metamorphic grade, although both compositions (illitic and muscovitic) are present in all samples (Abad et al., 2001; Abad et al., 2002).

The Ossa-Morena Zone Cambrian shales (López-Munguira \& Nieto, 2000) are located in the Variscan belt of SW Spain. The metamorphic evolution of this sequence (studied by XRD, SEM, TEM and EMPA) shows a progressive increase in the size of dioctahedral K-rich mica grains from diagenesis to epizone. These micas are illitic in diagenesis and anchizone, and phengitic in the epizone. The coexistence of different polytypes of mica and the absence of chemical homogeneity indicate disequilibrium in these rocks.

Sierra Espuña metapelitic rocks are located in the Internal Zones of the Betic Cordillera (SE Spain), the westernmost European Alpine chain, and constitute a complete sequence of pelitic rocks ranging from diagenetic to greenschist-facies metamorphic conditions. Prograde and retro- grade reactions, facilitated by tectonic stress, were established by XRD and electron microscopy (SEM, TEM and AEM) studies (Nieto et al., 1994; Abad et al., 2003b).

The Puncoviscana Formation is located in the Eastern Cordillera of NW Argentina. It is mainly composed of a pelite-greywacke turbidite sequence that has been affected by polyphase deformation due to superposed folding. The metamorphic grade established via KI and TEM observations indicate that this unit has undergone medium anchizonal- to epizonal-grade metamorphism. In addition, based on the Si content of dioctahedral micas, pressures from 5 to 7 kbar were reported for these metapelites in agreement with facies series derived from the b values (Do Campo, 1999; Do Campo \& Nieto, 2003).

The Talas Ala Tau shales are one of the most important outcrops of Precambrian rocks in the Tien Shan Ranges, which extend across Central Asia and within the North Tien Shan (Kyrgyz Republic). A crystal-chemical study of the phyllosilicates along a complete cross-section of this range reveals changes in their crystallinity, composition and lattice parameters. They were crystallized in very low-grade metamorphic conditions (anchizonal and epizonal grades) and the huge ranges for the phengitic content of micas at the 

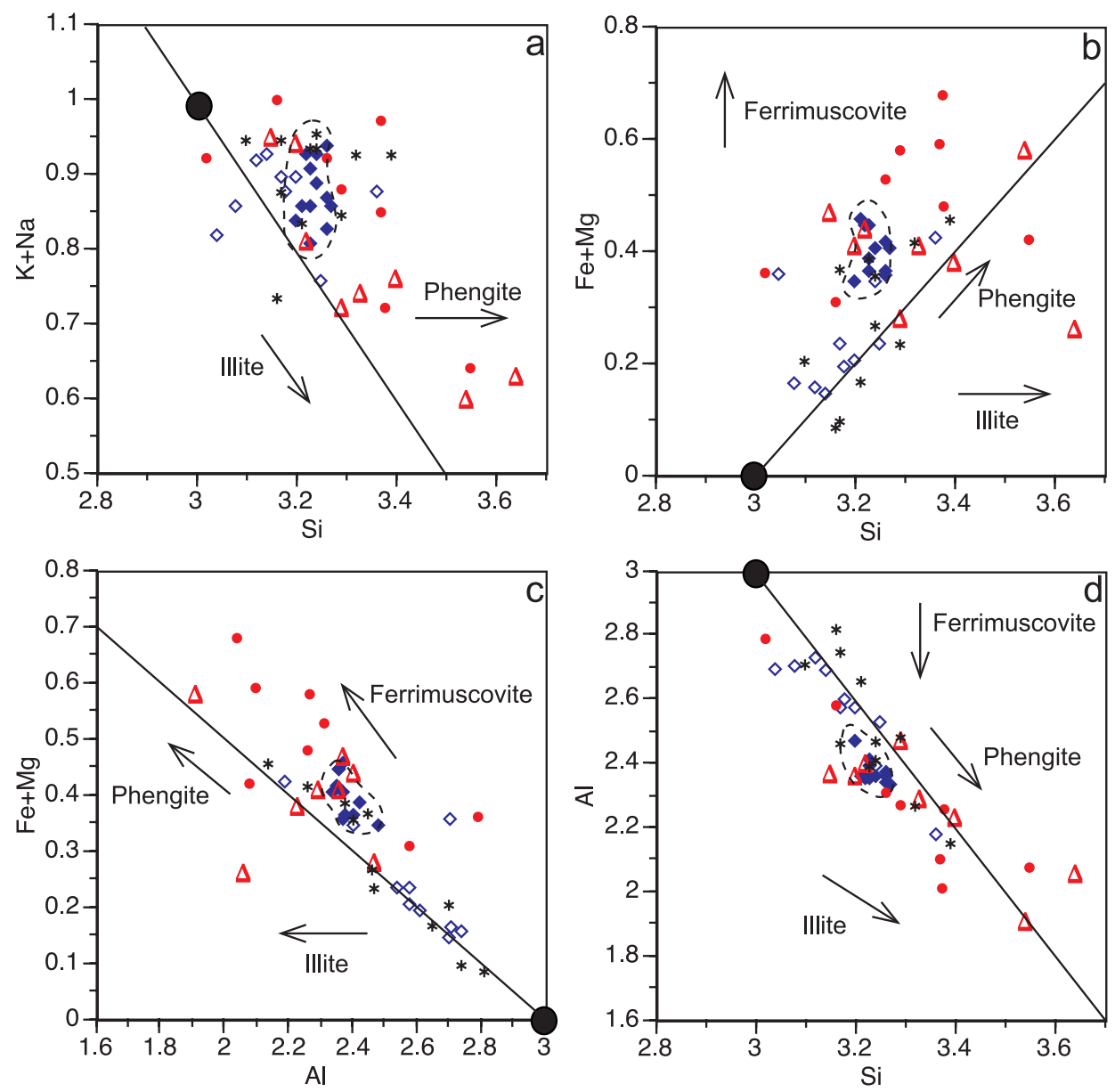

Fig. 6. Chemical diagrams illustrating the homogeneity $v s$. heterogeneity of $\mathrm{K}$-dioctahedral micas on the basis of only one selected sample representative of each grade of metamorphism (KI).

$$
\begin{array}{ll}
\diamond \text { epizone } \mathrm{KI}<0.2 & \bullet \text { high anchizone } \\
\diamond \text { epizone } \mathrm{KI}>0.2 & \Delta \text { low anchizone }
\end{array}
$$$$
\text { * diagenesis }
$$

sample level have been interpreted as the result of a decompression path from at least $8 \mathrm{kbar}$, possibly related to a geodynamic subduction environment (Abad et al., 2003c).

\section{Data}

All the analytical results are depicted in Table 1 (deposited at the Editorial Office, Paris) and the relations between different element contents are shown in Fig. 2, 3 and 4. Data corresponding to obvious detrital grains or micas from stacks have not been included. Figure 2 compares data obtained by SEM with those acquired using TEM. These graphs make it evident that the respective distribution fields for the chemical composition of micas are very similar for both techniques, thus evidencing the validity of the two methods to produce comparable analytical results of good quality. Even if the expected precision range for TEM is clearly lower, due to a higher error (3-12\% depending on the measured element), this error does not produce a significant effect in the distribution of the plotted data. Therefore, all the analytical results have been plotted together except for figures in which alkaline elements ( $\mathrm{K}$ and $\mathrm{Na}$ ) are considered. In these cases we have used only the SEM data, since TEM can be severely affected by alkali loss, as explained above.

One of the most evident and striking features in all the diagrams (Fig. 3) is the very similar behaviour of the micas included in the different sequences studied, with only minor deviations of some micas related with the high-pressure series (commented below).

The interpretation of the chemical composition of micas is complex because each chemical parameter is affected by several different compositional vectors. For example, the negative correlation between interlayer substitution and $\mathrm{Si}$ can be explained by illitic substitution (Fig. 3a and 4a). Nevertheless, the data do not exactly fit the theoretical line representing this compositional vector as the Si content is also strongly affected by phengitic substitution. The phengitic vector is the main one determining the proportion of $\mathrm{Si}, \mathrm{Al}$ and $\mathrm{Fe}+\mathrm{Mg}$ in dioctahedral micas and it is responsible for the positive correlation between $\mathrm{Si}$ and $\mathrm{Fe}+\mathrm{Mg}$ (Fig. 3b), and the negative correlations between $\mathrm{Al}$ and $\mathrm{Fe}+\mathrm{Mg}$ (Fig. 3c) or Al and Si (Fig.3d). The three diagrams are also 
influenced to some extent by the ferrimuscovitic vector, which produces contents higher in $\mathrm{Fe}$ and lower in $\mathrm{Al}$ than expected as a result only of the phengitic substitution.

The illitic substitution is present in each grain to different degrees in diagenetic and anchizonal samples and it also persists in the lower epizone (Fig. 4a). The interlayer charge populations range from 0.6 to 1.0 a.f.u., with the lowermost values related to the highest $\mathrm{Si}$ contents (around 3.4-3.6 a.f.u., Fig. 4a). This is always combined with different proportions of phengitic and ferrimuscovitic substitutions (Fig. $4 \mathrm{~b}$ and c) and in some cases with paragonitic substitution (not shown). The combination of these compositional vectors produces a lack of chemical equilibrium at the sample level. In a fine-grained matrix (Fig. 5a and c), these low-T micas are usually formed by straight packets, separated by low-angle boundaries (Nieto \& Abad, 2003).

Dioctahedral mica compositions do not show significant differences among samples from different grades except for the illitic component, which becomes insignificant in the most evolved epizone samples $\left(\mathrm{KI}<0.20 \Delta^{\circ} 2 \theta\right)$ with an interlayer charge population of $>0.8$ a.f.u. and a Si excess of over 3 a.f.u., which is fully compensated for the phengitic content. All these samples show an approach to chemical equilibrium, with only small differences in chemical composition among mica grains and have developed a main metamorphic cleavage (Fig. 5b and d) with well-differentiated phyllosilicate packets, lacking in defects and orientated parallel to each other (Nieto \& Abad, 2003).

An important question that arises is whether the high scattering in chemical compositions shown in Fig. 2, 3 and 4 derives from differences among samples or whether it is mainly a consequence of heterogeneous mica composition at the sample level. In order to investigate this further, we have plotted only one representative sample for each metamorphic grade in Fig. 6. This figure demonstrates that dioctahedral micas with a wide range of substitutions coexist in almost all samples. In fact, the compositional range displayed for the five selected samples covers nearly the same range of mica compositions exhibited by all the studied samples. The exception, again, is the higher-grade epizonal sample with $\mathrm{KI}<0.20 \Delta^{\circ} 2 \theta$, in which the mica compositions are more homogeneous. An alternative selection of different samples from the same grade groups has been made, producing the same results.

Lack of chemical equilibrium is also present in the lowgrade metamorphic sequences that have undergone a highpressure event, such as Talas Ala-Tau, or an event near the limit between intermediate and high pressure, such as the Puncoviscana Formation. In these cases phengitic substitution is the main vector determining the proportions of the major elements in white micas. In Puncoviscana, ferrimuscovitic substitution is also important. In contrast to the rest of the studied samples, the illitic component is not present in significant amounts in Talas Ala-Tau (Fig. 3a) and can be detected in only a few analyses in Puncoviscana samples. Therefore, some analyses of Talas Alas Tau and Puncoviscana samples plot outside the illitic tendency field (over the dotted line) in Fig. 3a, due to a significant increase in Si that is not correlated with low interlayer populations. This $\mathrm{Si}$ increase is in fact the consequence of very significant phengi- tic substitution. The absence of correlation between low interlayer populations and high Si contents is characteristic of these higher-pressure sequences and indicates a lack of significant illitic substitution.

\section{Discussion}

According to Árkai (2002), there are two progressive trends of phyllosilicate chemical changes that occur between early diagenesis to epizone. One of them is the post-sedimentary reaction: dioctahedral smectite $\rightarrow$ illite/smectite interstratified clay mineral $\rightarrow$ illite $\rightarrow$ dioctahedral white K-rich mica (muscovite). Since the role of illite, as a compositional vector in micas (Rieder et al., 1998), is still poorly known, in this study we have focused on the last portion of the aforementioned reaction (illite $\rightarrow$ muscovite) with the aim of understanding the way in which the illitic substitution evolves in response to prograde metamorphism. Due to the development of electron microscope techniques (SEM/EDX, TEM/ AEM), it is possible to obtain high-quality in situ analyses of coexistent illites and muscovites in low-grade metamorphic sequences.

When all these analyses from a varied set of very lowgrade sequences are plotted together (e.g. Fig. 3), one of the main features observed is the heterogeneity of the chemical compositions of the micas. Such general heterogeneity considering all the different samples and sequences is similar to the sample level (Fig. 6) and persists along the range from diagenesis to low epizone. The lack of equilibrium within a single sample at distances above a few millimetres denotes the coexistence of several mineral generations that did not re-equilibrate during P-T evolution (Worley et al., 1997). In agreement with our results, Vidal \& Parra (2000) found strong compositional heterogeneity among chlorites and phengites coexisting in the same thin section of metapelites metamorphosed at temperatures below $550{ }^{\circ} \mathrm{C}$. However, on a smaller scale, they identified local chlorite-phengite equilibrium. Each different equilibrium found in a single thin section, which involves minerals of different compositions, was linked to different micro-structural sites. These authors interpreted and quantified these compositional variations in terms of pressure and temperature variations using new thermodynamic solution models that account for Tschermak, di/trioctahedral, and pyrophyllitic (illitic) substitutions.

Local non-equilibrated chemical differences in each sample are a direct consequence of the heterogeneity of the sedimentary material that is the source for the metamorphic transformations. These heterogeneous materials also include detrital K-micas, which could have been partially affected by previous processes such as weathering or early diagenetic transformations. Obvious detrital micas were avoided during data acquisition, but fine-grained flakes without any textural signs of their detrital origin are also present in sediments and hence they may be included in the data presented. Such detrital precursors are probably a significant source, but not the exclusive one, of the afore-mentioned initial heterogeneity and they provide a scatter between illite and muscovite for a continuously variable 
chemical composition. Their ability to approach chemical equilibrium with solutions is severely affected by local factors such as permeability and strain.

The coexistence of illitic and muscovitic dioctahedral micas even at the sample level (Fig. 6) provides direct evidence of the lack of chemical equilibrium in slates formed at sub-greenschist conditions. As Merriman \& Peacor (1999) have pointed out, the lack of chemical equilibrium in these rocks invalidates the use of clay-mineral-related 'geothermometers' for accurate determination of temperature. However, other authors such as Perry \& Hower (1970) and McDowell \& Elders $(1980,1983)$ consider that K-deficient mica has its own equilibrium field at low temperatures $\left(<350{ }^{\circ} \mathrm{C}\right)$. Moreover, based on experimental investigations, Yates \& Rosenberg (1996, 1997 and 1998) provided direct evidence for the stability of end-member illite with respect to muscovite in a 100 to $250{ }^{\circ} \mathrm{C}$ temperature range through solid equilibration experiments. More recently, Agard et al. (2001) found a large decrease in interlayer content (ca. 0.9-0.7 a.f.u.) with decreasing P-T conditions in successive generations of retrograde phengite; they concluded that pyrophyllitic (illitic) substitution in phengite is large at low-temperature conditions and cannot be ignored. Árkai et al. (2003) have found that the composition of the Kmicas of the Meliata Unit (Western Carpathians) plotted mainly along the muscovite-phengite line, but slightly shifted towards the illite field due to small but significant deficits in interlayer charge, the deficits clearly being correlated with KI. The application of the chlorite-white mica thermobarometer of Vidal \& Parra (2000) to these interlayer-deficient mica compositions has provided compatible results with local equilibrium conditions on a microscopic scale.

Figure 4 shows that chemical analyses corresponding to the epizone samples with $\mathrm{KI}<0.20 \Delta^{\circ} 2 \theta$ and a clear metamorphic texture (Fig. 5b and d) have a notably different chemical behaviour. These micas have evolved to more homogeneous chemical compositions (Fig. 6), with an increase in $\mathrm{K}$ content in the interlayer ( $>0.8$ a.f.u.) and a richer aluminium composition, close to the end-member muscovite. That is, the importance of the illitic vector decreases as the incipient metamorphism advances. According to the conclusions of Frank et al. (1998), based on an experimental study, the K-deficient compositions are not stable above $400{ }^{\circ} \mathrm{C}$.

Figure 2 verifies that there is no effect from the two analytical techniques employed in the present study as the chemical results corresponding to SEM and TEM overlap. As well, contamination or other possible artefacts are easy to detect through the joint observation of Fig. 1 and Fig. 3 and 4 . This is an important point because, before the development of these techniques, the knowledge of the mineral chemistry of these phases depended on the interpretation of data obtained from mixtures of mineral phases or on the presence of more or less monomineralic occurrences of a given mineral. This is the case for Hower \& Mowatt (1966) or Srodon \& Eberl (1984), among others, who used bulk clay-mineral analyses and XRD data for establishing a 0.75 K a.f.u. as end-member illite. Ransom \& Helgeson (1993) used XRD and TEM/AEM data to avoid the impure samples and gave a value for the layer charge of illitic layers between
0.5 and 0.9 a.f.u. Grathoff \& Moore (2002) have even detected different amounts of fixed cations in the interlayer for coexistent illites with different polytypes, finding $\mathrm{K}$ contents for the $1 \mathrm{M}_{\mathrm{d}}$ polytype of around 0.67 a.f.u. and for the $2 \mathrm{M}_{1}$ polytype of approximately 0.78 a.f.u.

It is well known that the principal factors controlling the chemical and textural evolution in clastic rocks during incipient metamorphism are temperature and pressure; however, tectonic stress and time, which together imply deformation, are also very important factors in the development of metamorphic texture, mainly foliations, and the approach to chemical equilibrium (Abad et al., 2003a). Dioctahedral K-micas from different geological settings show similar chemical behaviour, which suggests that illitic substitution depends on the general geological conditions ( $\mathrm{P}$ and $\mathrm{T}$ ) more than on local factors such as lithology. On the other hand, its role is minimal in rocks formed in environments characterised by a high P/T gradient (Talas Ala Tau shales and Puncoviscana Formation), where phengitic substitution is the most significant chemical tendency (Fig. 3b and c) in agreement with Dalla Torre et al. (1996); in contrast, in LP/ LT or IP/LT environments, low temperature $\left(<300{ }^{\circ} \mathrm{C}\right)$ conditions result in a significant role for illitic substitution. Nevertheless, the conclusion regarding the variation in behaviour for the high $\mathrm{P} / \mathrm{T}$ gradient sequences may be limited only to medium-high anchizonal and epizonal conditions as no data are available for lower-grade cases.

Figure 3 shows that the highest $\mathrm{Si}$ contents correspond not only to micas from HP/LT sequences, but also to others that formed under different P-T conditions. In detail, some of the mica analyses reaching Si contents of around 3.5 a.f.u. are free of illitic substitution (Talas Alas Tau and Puncoviscana), whereas in others these high values indicate "true" illites, which correspond to diagenesis-low anchizone with interlayer-cation populations contents in the range of 0.60.7 a.f.u. Therefore, as Agard et al. (2001) pointed out, thermobarometric estimates based exclusively on the Si-content, without taking into account the illitic component of low-temperature phengites, would result in pressure overestimates. Although considerable chemical and textural data has been obtained by SEM/EDX and TEM/AEM in recent years, the precise relationships between illite and muscovite remain unsolved (Rosenberg, 2002). In this paper we present evidence of the coexistence of K-deficient micas with muscovite in natural samples belonging to several lowgrade metamorphic sequences. Even though some experimental data suggest the existence of a miscibility gap between illite and muscovite (Yates \& Rosenberg, 1998), this is not so evident in natural environments. We agree with Rosenberg (2002) that more detailed chemical and textural TEM studies of end-member illite are necessary in order to obtain direct evidence supporting the hypothesis of illitic mica as an ordered structure based on muscovite and pyrophyllite domains.

\section{Conclusions}

Illitic substitution is present in each mica grain in varied percentages (interlayer populations ranging from 0.6 to 1.0 
a.f.u.) in diagenetic and anchizonal samples of clastic rocks and continues into the lower epizone rocks. In more evolved epizone rocks $\left(\mathrm{KI}<0.20 \Delta^{\circ} 2 \theta\right)$, the illitic component, in the IMA nomenclature sense, becomes insignificant (interlayer population $>0.8$ a.f.u. and Si excess over 3 a.f.u. fully compensated by the phengitic component), although maintaining small differences in chemical composition among mica grains.

The chemical composition of K-dioctahedral micas in low-T environments is highly heterogeneous and depends on several exchange vectors. Together with phengitic, ferrimuscovitic and paragonitic substitutions, which are well established at higher grades, the illitic vector predominates under incipient metamorphic conditions. Our data suggest continuity in the composition between illite and muscovite and do not allow us to confirm the existence of a miscibility gap in low-T environment natural samples.

The heterogeneity of the chemical data in the diagenesisanchizonal samples indicates the importance of local composition at the beginning of metamorphic transformations. Nevertheless, when high epizone conditions are reached (KI $<0.20 \Delta^{\circ} 2 \theta$ ), the significant textural changes that take place imply an approach to chemical homogeneity with disappearance of the illitic vector.

Acknowledgments: Financial support has been supplied by the Research Projects BTE2003-07867-C02-02 and BTE2003-07867-C02-01 (Spanish Ministry of Science and Technology) and the Research Groups RNM-019 and RNM-325 (Junta de Andalucía). Christine Laurin is akknowledged for reviewing the English. Thanks are extended to P. Árkai, B. Fritz and T. Balic-Zunic for their critical reviews and very helpful comments.

\section{References}

Abad, I., Nieto, F., Velilla, N., Mata, P. (2001): The phyllosilicates in diagenetic-metamorphic rocks of the South Portuguese Zone, southwestern Portugal. Can. Mineral., 39, 1571-1589.

Abad, I., Nieto, F., Velilla, N. (2002): Chemical and textural characterisation of diagenetic to low-grade metamorphic phyllosilicates in turbidite sandstones of the South Portuguese Zone: A comparison between metapelites and sandstones. Schweiz. Mineral. Petrogr. Mitt., 82, 303-324.

Abad, I., Nieto, F., Gutiérrez-Alonso, G. (2003a): Textural and chemical changes in slate-forming phyllosilicates across the external-internal zones transition in the low-grade metamorphic belt of the NW Iberian Variscan Chain. Schweiz. Mineral. Petrogr. Mitt., 83, 63-80.

Abad, I., Nieto, F., Peacor, D.R., Velilla, N. (2003b): Prograde and retrograde diagenetic and metamorphic evolution in metapelitic rocks of Sierra Espuña (Spain). Clay Miner., 38, 1-23.

Abad, I., Gutiérrez-Alonso, G., Nieto, F., Gertner, I., Becker, A., Cabero, A. (2003c): The structure and the phyllosilicates (chemistry, crystallinity and texture) of Talas Ala-Tau (Tien-Shan, Kyrgyz Republic): comparison with more recent subduction complexes. Tectonophysics, 365, 103-127.

Agard, P., Vidal, O., Goffé, B. (2001): Interlayer and Si content of phengite in HP-LT carpholite-bearing metapelites. J. Metamorphic Geol., 19, 477-493.
Árkai, P. (2002): Phyllosilicates in Very Low-grade Metamorphism: transformation to Micas. in "Reviews in Mineralogy and Geochemistry", "Advances in micas". Mineralogical Society of America, Washington D.C., 46, 463-478.

Árkai, P., Faryad, S.W., Vidal, O., Balogh, K. (2003): Very lowgrade metamorphism of sedimentary rocks of the Meliata Unit, Western Carpathians, Slovakia: Implications of phyllosilicate characteristics. Int. J. Earth Sci., 92, 68.

Bailey, S.W. (1966): The status of clay mineral structures. Proceedings of the $14^{\text {th }}$ National Conference on Clays and Clay Minerals. Pergamon Press, 1-23.

Cliff, G. \& Lorimer, G.W. (1975): The quantitative analyses of thin specimens. J. Microscopy, 103, 203-207.

Dalla Torre, M., Livi, J.T.K., Veblen, D.R., Frey, M. (1996): White $\mathrm{K}$-mica evolution from phengite to muscovite in shales and shale matrix melange, Diablo Range, California. Contrib. Mineral. Petrol., 123, 390-405.

Do Campo, M. (1999): Metamorfismo del basamento en la Cordillera Oriental y borde oriental de la Puna. in "Relatorio XIV Congreso Geológico Argentino Geología del Noroeste Argentino", G. González Bonorino, R. Omarini, J. Viramonte, eds. Universidad de Salta, Salta, 41-51.

Do Campo, M. \& Nieto, F. (2003): Transmission electron microscopy study of very low-grade metamorphic evolution in Neoproterozoic pelites of the Puncoviscana formation (Cordillera Oriental, NW Argentina). Clay Miner., 38, 459-481.

Frank, M.R., Candela, P.A., Piccoli, P.M. (1998): K-feldspar-muscovite-andalusite-quartz-brine phase equilibria: An experimental study at 25 to $60 \mathrm{MPa}$ and 400 to $500{ }^{\circ} \mathrm{C}$. Geochim. Cosmochim. Acta, 62, 3717-3727.

Gharrabi, M., Velde, B., Sagon, J.P. (1998): The transformation of illite to muscovite in pelitic rocks: Constraints from X-ray Diffraction. Clays Clay Miner., 46, 79-88.

Grathoff, G.H. \& Moore, D.M. (2002): Characterization of the Waukesha Illite: A mixed-polytype illite in the Clay Mineral Society repository. Am. Miner., 87, 1557-1563.

Grim, R.E., Bray, R.H., Brandley, W.F. (1937): The mica in argillaceous sediments. Am. Miner., 22, 813-829.

Guidotti, C.V. \& Sassi, F.P. (1998): Petrogenetic significance of Na$\mathrm{K}$ white mica mineralogy: Recent advances for metamorphic rocks. Eur. J. Mineral., 10, 815-854.

Guidotti, C.V., Yates, M.G., Dyar, M.D., Taylor, M.E. (1994): Petrogenetic implications of the $\mathrm{Fe}^{3+}$ content of muscovite in pelitic schists. Am. Miner., 79, 793-795.

Gutierrez-Alonso., G. \& Nieto., F. (1996): White mica "crystallinity", finite strain and cleavage development across a large structure (Narcea Antiform, Variscan belt of NW Spain). J. Geol. Soc., 153, 287-299.

Hower, J. \& Mowatt, T.C. (1966): The mineralogy of illites and mixed-layer illite/montmorillonites. Am. Miner., 51, 825-854.

Hower, J., Hurley, P.M., Pinson, W.H., Fairbairn, H.W. (1963): The dependence of $\mathrm{K}-\mathrm{Ar}$ age on the mineralogy of various particle size ranges in a shale. Geochim. Cosmochim. Acta, 27, 405-410.

Hunzinker, J.C., Frey, M., Clauer, N., Friedrichsen, H., Flehmig, W., Hochstrasser, K., Roggwiler, P., Schwander, H. (1986): The evolution of illite to muscovite: mineralogical and isotopic data from the Glarus Alps, Switzerland. Contrib. Mineral. Petrol., 92, 157-180.

Kisch, H.J. (1991): Development of slaty cleavage and degree of very-low-grade metamorphism: a review. J. Metamorphic Geol., 9, 735-750.

Livi, K.J.T., Veblen, D.R., Ferry, J.M., Frey, M. (1997): Evolution of 2:1 layered silicates in low-grade metamorphosed Liassic shales of Central Switzerland. J. Metamorph. Geol., 15, 323-344. 
López-Munguira, A. \& Nieto, F. (2000): Transmission electron microscopy study of very low-grade metamorphic rocks in Cambrian sandstones and shales, Ossa-Morena Zone, Southwest Spain. Clays Clay Miner., 48, 213-223.

McDowell, S.D. \& Elders, W.A. (1980): Authigenic layer silicate minerals in borehole Elmer 1, Salton Sea geothermal field, California, U.S.A. Contrib. Mineral. Petrol., 74, 293-310.

-,- (1983): Allogenic layer silicate minerals in borehole Elmo \#1, Salton Sea Geothermal Field, California. Am. Miner., 68, 11461159.

Merriman, R.J. \& Peacor, D.R. (1999): Very low-grade metapelites: mineralogy, microfabrics and measuring reaction progress. in "Low grade-metamorphism", M. Frey \& D. Robinson, eds. Blackwell Science, Oxford.

Nadeau, P.H. \& Bain, D.C. (1986): Composition of some smectites and diagenetic illitic clays and implications for their origin. Clays Clay Miner., 34, 455-464.

Nieto, F. \& Abad, I. (2003): X-Ray Diffraction Parameters in Very Low-Grade metamorphism Seen in the "Light" of TEM. in "Applied study of cultural heritage and clays" J.L. Pérez Rodríguez, ed. Consejo Superior de Investigaciones Científicas, Madrid, 83, 363-376.

Nieto, F., Velilla, N., Peacor, D.R., Ortega-Huertas, M. (1994): Regional retrograde alteration of sub-greenschist facies chlorite to smectite. Contrib. Mineral. Petrol., 115, 243-252.

Nieto, F., Ortega-Huertas, M., Peacor, D.R., Aróstegui, J. (1996): Evolution of illite/smectite from early diagenesis through incipient metamorphism in sediments of the Basque-Cantabrian Basin. Clays Clay Miner., 44, 304-323.

Perry, E. \& Hower, J. (1970): Burial diagenesis in Gulf Coast pelitic sediments. Clays Clay Miner, 18, 165-176.

Pouchou, J.L. \& Pichoir, F. (1985): "PAP" $(\phi)(\rho)(\mathrm{z})$ procedure for improved quantitative microanalysis. in "Microbeam Analysis" J.T. Armstrong, ed. San Francisco Press, San Francisco.

Ransom, B. \& Helgeson, H.C. (1993): Compositional end members and thermodynamic components of illite and dioctahedral aluminous smectite solid solutions. Clays Clay Miner., 41, 537-550.

Rieder, M., Cavazzini, G., D’Yakonov, Y.S., Kamanetskii, V.A.F., Gottardi, G., Guggenheim, S., Koval, P.K., Müller, G., Neiva, A.M.R., Radoslovich, E.W., Robert, J.L., Sassi, F.P., Takeda, H., Weiss, Z., Wones, D.R. (1998): Nomenclature of the micas. Can. Mineral., 36, 905-912.
Rosenberg, P.E. (2002): The nature, formation, and stability of endmember illite: A hypothesis. Am. Miner, 87, 103-107.

Srodon, J. (1999): Extracting K-Ar ages from shales: a theoretical test. Clay Miner., 33, 375-378.

Srodon, J. \& Eberl, D.D. (1984): Illite. in "Reviews in Mineralogy: Micas" S.W. Bailey, ed. Mineralogical Society of America, Washington D.C., 13, 495-544.

Srodon, J., Elsass, F., McHardy, W.J., Morgan, D.J. (1992): Chemistry of illite-smectite inferred from TEM measurements of fundamental particles. Clay Miner., 27, 137-158.

Vidal, O. \& Parra, T. (2000): Exhumation paths of high-pressure metapelites obtained from local equilibria for chlorite-phengite assemblages. Geol. J., 35, 139-161.

Warr, L.N. \& Rice, H.N. (1994): Interlaboratory standardization and calibration of clay mineral crystallinity and crystallite size data. J. Metamorphic. Geol., 12, 141-152.

Weaver, C.E. (1956): The distribution and identification of mixedlayer clays in sedimentary rocks. Am. Miner., 41, 202-221.

Worley, B., Powell, R., Wilson, C. (1997): Crenulation cleavage formation: Evolving diffusion, deformation and equilibration mechanisms with increasing metamorphic grade. J. Struct. Geol., 19, 1121-1135.

Yates, D.M. \& Rosenberg, P.E. (1996): Formation and stability of end-member illite: I. Solution equilibration experiments at 100 to $150^{\circ} \mathrm{C}$ and $\mathrm{P}_{\mathrm{v}, \text { soln }}$. Geochim. Cosmochim. Acta, 60, 1873-1883.

-,- (1997): Formation and stability of end-member illite: II. Solid equilibration experiments at 100 to $250^{\circ} \mathrm{C}$ and $\mathrm{P}_{\mathrm{v}, \mathrm{soln}}$. Geochim. Cosmochim. Acta, 61, 3135-3144.

,-- (1998): Characterization of neoformed illite from hydrothermal experiments at $250^{\circ} \mathrm{C}$ and $\mathrm{P}_{\mathrm{v}, \text { soln }}$ : An HRTEM/ATEM study. Miner., 83, 1199-1208.

Zhao, G., Peacor, D.R., McDowell, S.D. (1999): "Retrograde diagenesis" of clay minerals in the Precambrian Freda sandstone, Wisconsin. Clays Clay Miner., 47, 119-130.

Received 31 January 2005

Modified version received 23 June 2005

Accepted 19 September 2005 